\title{
A Gender-Based Analysis of Saudi EFL Learners' Approaches towards Outcome-Based Education: Learning Outcomes and Teaching Resources in Focus
}

\author{
Mansoor S. Almalki* \\ English Language Centre, Deanship of Supportive Studies, Taif University, Taif 21974, Saudi Arabia \\ *Corresponding Author: Mansoor S. Almalki, English Language Centre, Deanship of Supportive \\ Studies, Taif University, Taif 21974, Saudi Arabia
}

\begin{abstract}
This study analyzes the viewpoints of male and female students to see any difference in their approach towards the effectiveness of Outcome-Based Education (OBE) in their English as a Foreign Language (EFL) classroom. The research also investigates their whether there in any difference in the opinions of male and female students in terms of the effect the effectiveness of the textbooks as well as the online study material. Moreover, an attempt has also been made to see how differently male and female students approach the effectiveness of Course Learning Outcome (CLOS). For this research, 200 questionnaires were equally distributed among male and female students enrolled in the four different disciplines and studying English as a compulsory course. Out of 200 questionnaires, 148 were returned by 75 male and 73 female students. The data was analyzed through SPSS and presented with help of descriptive tables, group tests, and independent Samples test. Results from the analysis show that female students, in comparison to their male counterparts showed greater belief in not only the efficacy of the teaching material but also the relevance of their learning outcomes. As a step forward, the study recommends to address the relevant issues, with special reference to the responses of the male students, to improve the related CLOs and the overall teaching material.
\end{abstract}

Keywords: Gender-Based Analysis, Course Learning Outcome (CLOs), Outcome-Based Education (OBE), English as a Foreign Language (EFL)

\section{INTRODUCTION}

Be it for accreditation processes or solely educational purposes, several reforms have, so far, taken place as a result of the continuous uplift endeavors in the educational administration over the past several years (Satish \& Gaitonde, 2019; Hermanani, 2017; Brookhart, 2015). These developments range from the introduction of globalizations models to transformative models, community and school based models, decentralized models, centralized models and neo-colonial models (Okiror, Hayward \& Winterbottom, 2017; Cummings \& Williams, 2005). One of the offshoots of these administrative reforms was the emergence of Outcome-Based Education (OBE) that based its mission on the lines of ensuring accountability and quality in higher education (Spady, 1994; Ungar, 1996). Following the considerable impact of OBE on higher educational administration worldwide, the usage of terms in assessment such as learning outcomes multiplied a great deal while referring to variables like learner's competencies, performance and results (Spady, 2003).

\section{BACKGROUND TO OUTCOME-BASED EDUCATION}

To start with, OBE is the complete package of not only teaching but also curriculum design and assessment procedures that culminates into developing the learner's actual abilities in the form of the learning outcomes. Such is the all-inclusive nature of this whole process that it tries to encompass the learner's cultural, economic and social setting by inculcating the related issues in the individual learning outcomes. Spady (1994) categorizes OBE into three major types:

- If the established curriculum is used to measure the learner's learning outcomes, it comes under the domain of Traditional OBE.

- If higher-order competencies such as teamwork, communication skills, problem solving, and critical thinking are used to measure the learner's learning outcomes, it is called the Transitional OBE. 
- If the disciplinary knowledge as well as values, attitudes, generic competencies, and the related skills, which are the specific requirements of a particular society or industry, are considered as the yardstick for measuring the learner's learning outcomes, it comes under the domain of the Transformational OBE.

As part of the transformational OBE, stakeholders such as the community, parents of the learners, faculty and learners jointly collaborate to develop the assessments, teaching material and the overall curriculum to be used. Multiple assessment and instructional tool and strategies including developing student's portfolio, assigning oral presentations, project, quizzes, and assignments to accommodate every learner's learning outcomes and needs (Ungar, 1996). Other than lectures, teachers use elearning, peer tutoring, fieldwork, self-directed learning, tutorial, observation, role play, simulation, problem-based learning and case-based learning to ensure that learners achieve the target learning outcomes. Assessment methods in OBE range from peer and self-assessment to examinations, portfolio assessment, practicum, presentations, reflective journal, end of chapter problem solutions, projects, essays and objective tests, depending on the level of the students (Ploy, 2008).After rigorous studies during the semester, measureable criterion-based standards are used to assess the performance of the learners in terms of their attainment of the course learning outcomes. OBE does not follow or recognize assessment methods such as tests and examinations which are norm-based.

\section{RATIONALE FOR THE CURRENT STUDY}

In order for OBE to be successful in its attainment of the learners' learning outcomes, it is pertinent to ensure that all teachers as well as learners understand the information pertaining to the overall system of OBE and the related activities (Lundahl, Hultén and Tveit2017; Lindhorst and Schulenlenberg, 2006). In the same vein, Ruhland and Brewer (2001) also highlight the importance of taking into consideration the learners' approach towards the whole process, saying that the learners must know about the affective and cognitive development through the learning outcomes (Ruhland and Brewer, 2001). Morton, Well and Cox (2019) highlight the immense importance of learners' engagement in the whole learning process, terming it the involvement pf the learners as part of the implicit curriculum. With reference to OBE, Ungar (1996) says that the learners' take on every detail in the process is importance, adding that OBE develops multiple assessment and instructional tool and strategies, including developing student's portfolio, assigning them oral presentations, projects, quizzes, and assignments to accommodate every learner's learning outcomes and needs.

Keeping in view the importance of learners' engagement in the whole process of curriculum as well as assessment towards the successful carrying out of OBE, the present study investigates to see if there are differences in the approaches of male and female students towards OBE in general and the available teaching material in particular. As Cin, Dennis and Temiz (2018) highlight the importance of gender-equality in educational policy-making, the current study takes into consideration the perceptions of the female learners alongside their male counterparts for a more holistic view of the efficacy of OBE in the present context.

\section{CONTEXT OF THE STUdY}

Taif University English Language Centre offers a variety of English courses to the students of different streams in accordance with requirements and needs of the students: English for Academic Purposes (EAP) and English for Specific Purposes (ESP). EAP courses are further categorized into Regular EAP (REAP) and Intensive REAP (IEAP). IEAP course is offered to the students enrolled in Medicine, Pharmacy, Computer science and Engineering programs. In this intensive English course students take 12 face to face and 3 online hours to cover two levels (A1 \& A2) of English Unlimited of Cambridge University Press to complete the requirements of the course.

This new course was introduced after thorough analysis of the needs and requirements of the students. The current study is a part of full project to evaluate the significance of English Unlimited in terms of its efficacy and sufficiency towards the learners' attainment of their course learning outcomes. This research seeks to understand learners' experience from the perspective of their gender. This comparative analysis of the male and female students' responses brings forth any differences in their approach towards not only OBE in general but the also the efficacy and sufficiency of the teaching material available to them. 
A Gender-Based Analysis of Saudi EFL Learners' Approaches towards Outcome-Based Education: Learning Outcomes and Teaching Resources in Focus

\section{OBJECTIVES OF THE STUDY}

The main objective of the current study is to find out if there is any difference of opinion between male and female students about the nature, structure, and contents of English course books in terms of the efficacy and sufficiency of the teaching material in achieving the learning outcomes. To achieve the objective, the researcher tries to answer the following questions:

\section{RESEARCH QUESTIONS}

The study endeavors to answer the following research questions:

- How do male and female EFL learners differ in their learning approaches towards Outcomebased learning?

- In what ways do male and female learners see the efficacy of EFL textbooks towards Outcome-based learning?

\section{Data Analysis, Results AND Discussion}

A total of, 200 questionnaires were equally distributed among male and female students enrolled in the four different disciplines (mentioned earlier). Out of the 200 questionnaires, 148 were returned (male 75) and (73 female). The data analyzed through SPSS is presented with the help of descriptive tables, group tests, and independent Samples test. The questionnaire has four sections. Thus, the results are presented in sections.

Table1. Course Learning Outcomes and Effectiveness of Outcome-Based Education

\begin{tabular}{|l|l|l|l|}
\hline \multicolumn{1}{|c|}{ Appropriateness of Textbooks Towards Course Learning Outcomes } & N & Mean & $\begin{array}{c}\text { Std. } \\
\text { Deviation }\end{array}$ \\
\hline $\begin{array}{l}\text { The level of this course was appropriate towards attainment of the course } \\
\text { learning outcomes. }\end{array}$ & 148 & 3.66 & 1.271 \\
\hline Learning English through Outcome-Based approach is important for me. & 148 & 4.07 & 1.281 \\
\hline
\end{tabular}

The above table shows that there are just two question asking about the suitability of the textbooks towards the attainment of course learning outcomes, and how much OBE is beneficial for students in their EFL classroom. The mean value (4.07) suggests that students deem that learning English through OBE is very beneficial to them. As the results in above table show, the students also believe that the level of the course is a1ppropriate towards their attainment of the related course learning outcomes. This is proved by the mean value of 3.66 that is far above the neutral value; however, the mean value of the first question is less than the second one. This suggests that the level of the course is little lower than their expectation of how important OBE is towards their learning of English language in the classroom.

Table2. Group Statistics and Independent Sample Tests on Course Learning Outcome and OBE

\section{Group Statistics}

\begin{tabular}{|c|c|c|c|c|c|}
\hline \multicolumn{2}{|l|}{ Q3 } & $\mathbf{N}$ & Mean & Std. Deviation & Std. Error Mean \\
\hline \multirow{2}{*}{$\begin{array}{l}\text { The level of this course was } \\
\text { appropriate towards attainment of the } \\
\text { course learning outcomes. }\end{array}$} & Male & 75 & 3.41 & 1.175 & .136 \\
\hline & Female & 73 & 3.90 & 1.325 & .155 \\
\hline \multirow{2}{*}{$\begin{array}{l}\text { Learning English through Outcome- } \\
\text { Based approach is important for me. }\end{array}$} & Male & 75 & 4.44 & 1.017 & .117 \\
\hline & Female & 73 & 3.68 & 1.413 & .165 \\
\hline
\end{tabular}

\section{Independent Samples Test}

\begin{tabular}{|c|c|c|c|c|c|c|c|c|c|}
\hline & \multicolumn{2}{|c|}{$\begin{array}{c}\text { Levene's Test } \\
\text { for Equality of } \\
\text { Variances } \\
\end{array}$} & \multicolumn{7}{|c|}{ t-test for Equality of Means } \\
\hline & \multirow[t]{2}{*}{$\mathbf{F}$} & \multirow[t]{2}{*}{ Sig. } & \multirow[t]{2}{*}{$\mathbf{t}$} & \multirow[t]{2}{*}{ df } & \multirow[t]{2}{*}{\begin{tabular}{|c|} 
Sig. \\
$(2-$ \\
tailed $)$
\end{tabular}} & \multirow[t]{2}{*}{$\begin{array}{c}\text { Mean } \\
\text { Difference }\end{array}$} & \multirow[t]{2}{*}{$\begin{array}{l}\text { Std. Error } \\
\text { Difference }\end{array}$} & \multicolumn{2}{|c|}{$\begin{array}{l}\text { 95\% Confidence } \\
\text { Interval of the } \\
\text { Difference }\end{array}$} \\
\hline & & & & & & & & Lower & Upper \\
\hline \begin{tabular}{l|l} 
The level of this & Equal \\
course was app & variances \\
ropriate towards & assumed
\end{tabular} & .130 & .719 & -2.386 & 146 & .018 & -.491 & .206 & -.897 & -.084 \\
\hline
\end{tabular}


A Gender-Based Analysis of Saudi EFL Learners' Approaches towards Outcome-Based Education: Learning Outcomes and Teaching Resources in Focus

\begin{tabular}{|c|c|c|c|c|c|c|c|c|c|c|}
\hline $\begin{array}{l}\text { attainment of the } \\
\text { course learning } \\
\text { outcomes. }\end{array}$ & \begin{tabular}{|l|} 
Equal \\
variances not \\
assumed
\end{tabular} & & & -2.382 & $\begin{array}{l}142 . \\
945\end{array}$ & .019 & -.491 & .206 & -.898 & -..084 \\
\hline $\begin{array}{l}\text { Learning } \\
\text { English through } \\
\text { Outcome-Based }\end{array}$ & \begin{tabular}{|l} 
Equal \\
variances \\
assumed
\end{tabular} & 7.346 & .008 & 3.739 & 146 & .000 & .755 & .202 & .356 & 1.154 \\
\hline $\begin{array}{l}\text { approach } \\
\text { important } \\
\text { me. }\end{array}$ & \begin{tabular}{|l|} 
Equal \\
variances not \\
assumed
\end{tabular} & & & 3.723 & $\begin{array}{l}130 . \\
578\end{array}$ & .000 & .755 & .203 & .354 & 1.156 \\
\hline
\end{tabular}

Looking at the mean value in the table of group statistics, there is no much difference of opinion between male and female learners as for the suitability of the textbooks towards the attainment of the related course learning outcomes is concerned. However, the results show that the female students agree a little more than the male students, as shown in the mean value (female $3.9 \pm 1.32$ ) against (male 3.41 \pm 1.17 ). Despite this, the study found that the responses of male students with the mean value (4.44 \pm 1.01$)$ is far higher than those of female students $(3.86 \pm 1.41)$, suggesting that male students consider learning English through OBE more important and beneficial than the female learners. The independent sample test for the first question shows $\mathrm{p}$ value as ".018," which is below ".05." This suggests that there is a significant difference between opinions of the male and female students about the appropriateness of the course towards the attainment of the course learning outcomes. However, this difference of opinion is statistically more different for the question asking about "how much important it is to use OBE in the classroom for learning English." As the p value for it is ".001," it suggests that there is significant difference between the opinions of the students in terms of their gender.

Male and Female Learners' Perceptions about Efficacy of Exercises and Tasks towards Learning Outcomes in their EFL Classroom:

Table3. Efficacy of Exercises and Tasks towards Attainment of Learning Outcomes

\begin{tabular}{|l|l|l|l|}
\hline \multicolumn{1}{|c|}{ Exercises and Tasks } & N & Mean & $\begin{array}{c}\text { Std. } \\
\text { Deviation }\end{array}$ \\
\hline The reading exercises and tasks in the course book were suitable for my level. & 148 & 3.55 & 1.392 \\
\hline The course gave me opportunities to practise speaking. & 148 & 3.64 & 1.330 \\
\hline The listening activities were suitable and helped me develop my listening skill. & 148 & 3.33 & 1.367 \\
\hline The writing tasks were achievable. & 148 & 3.55 & 1.295 \\
\hline $\begin{array}{l}\text { The number of new words introduced in every lesson was appropriate for this } \\
\text { level. }\end{array}$ & 148 & 3.54 & 1.377 \\
\hline $\begin{array}{l}\text { The vocabulary exercises in the course book were suitable and helped me learn } \\
\text { new vocabulary. }\end{array}$ & 148 & 3.37 & 1.377 \\
\hline The grammar points were presented with appropriate examples and explanations. & 148 & 3.50 & 1.383 \\
\hline There was sufficient attention to pronunciation and individual sounds. & 148 & 3.36 & 1.370 \\
\hline During this course I participated fully in class learning activities. & 148 & 3.42 & 1.400 \\
\hline Valid N (listwise) & 148 & & \\
\hline
\end{tabular}

The above table shows that the mean value is above the neutral value (2.5) for each of the statement. Overall, the majority of the learners think that the exercises and task are appropriate towards the attainment of the course learning outcomes with the mean value $(3.55 \pm 1.392)$. The learners are more satisfied with their speaking practice activities $(3.64 \pm 1.330)$, followed by the writing tasks (3.55 \pm 1.295$)$, the new words introduced in every lesson $(3.54 \pm 1.377)$, and the grammar point with better explanation (3.50 \pm 1.383$)$. The lowest mean value was reported for listening activities (3.33 $\pm 1.367)$ and pronunciation and individual sounds $(3.36 \pm 1.370)$. Overall, the students were satisfied with the efficacy and sufficiency of the exercises and activities, given in the textbooks.

Table4. Group Statistics on Efficacy of Exercises and Tasks towards Attainment of Learning Outcomes

\begin{tabular}{|l|l|l|l|l|l|}
\hline \multicolumn{9}{|c|}{ Group Statistics } & & & \multicolumn{1}{c|}{$\begin{array}{c}\text { Std. } \\
\text { Q3 }\end{array}$} & N & Meviation & $\begin{array}{c}\text { Std. Error } \\
\text { Mean }\end{array}$ \\
\hline $\begin{array}{l}\text { The reading exercises and tasks in the course book } \\
\text { were suitable for my level. }\end{array}$ & Male & 75 & 3.29 & 1.393 & .161 \\
\cline { 2 - 7 } $\begin{array}{l}\text { The course gave me opportunities to practise } \\
\text { speaking. }\end{array}$ & Male & 75 & 3.65 & 1.214 & .140 \\
\cline { 2 - 7 } & Female & 73 & 3.63 & 1.448 & .170 \\
\hline
\end{tabular}


A Gender-Based Analysis of Saudi EFL Learners' Approaches towards Outcome-Based Education: Learning Outcomes and Teaching Resources in Focus

\begin{tabular}{|l|l|l|l|l|l|} 
The listening activities were suitable and helped me & Male & 75 & 3.35 & 1.351 & .156 \\
\cline { 2 - 6 } develop my listening skill. & Female & 73 & 3.32 & 1.393 & .163 \\
\hline The writing tasks were achievable. & Male & 75 & 3.59 & 1.264 & .146 \\
\cline { 2 - 6 } & Female & 73 & 3.52 & 1.334 & .156 \\
\hline The number of new words introduced in every & Male & 75 & 3.64 & 1.291 & .149 \\
\cline { 2 - 6 } lesson was appropriate for this level. & Female & 73 & 3.44 & 1.462 & .171 \\
\hline The vocabulary exercises in the course book were & Male & 75 & 3.63 & 1.250 & .144 \\
\cline { 2 - 6 } suitable and helped me learn new vocabulary. & Female & 73 & 3.11 & 1.458 & .171 \\
\hline $\begin{array}{l}\text { The grammar points were presented with } \\
\text { appropriate examples and explanations. }\end{array}$ & Male & 75 & 3.59 & 1.264 & .146 \\
\cline { 2 - 6 } $\begin{array}{l}\text { There was sufficient attention to pronunciation and } \\
\text { individual sounds. }\end{array}$ & Memale & 73 & 3.41 & 1.498 & .175 \\
\hline During this course I participated fully in class & Female & 73 & 3.27 & 1.465 & .171 \\
\cline { 2 - 6 } learning activities. & Male & 75 & 3.37 & 1.363 & .157 \\
\hline
\end{tabular}

Comparing the mean value reported seperately for both male and female students against each question item of this section in the group Statistics Table, the results show that there is no big difference found between the opinions of male and female students. It is very interesting to note that the students were found more satisfied with listening practice actvities compared to other tasks. The group statistics table shows that the least difference is found (male 3.35 and female 3.32 ) in their opinions about the listening practice actvities. The highest difference is found in their opinion about the vocabularly exercises (male 3.63 and female 3.11), followed by the reading exercises and tasks (male 3. 29 andfemale 3.89).This suggests that the male students were more satisfied with the vocabulary exercises, compared to the female students.

Table5. Independent Sample Tests on Efficacy of Exercises and Tasks towards Attainment of Learning Outcomes

\begin{tabular}{|c|c|c|c|c|c|c|c|c|c|c|}
\hline \multicolumn{11}{|c|}{ Independent Sample Test } \\
\hline & & \multicolumn{2}{|c|}{\begin{tabular}{|c|} 
Levene's Test \\
for Equality \\
of Variances \\
\end{tabular}} & \multicolumn{7}{|c|}{ t-test for Equality of Means } \\
\hline & & \multirow[t]{2}{*}{$\mathbf{F}$} & \multirow[t]{2}{*}{ Sig. } & \multirow[t]{2}{*}{$\mathbf{t}$} & \multirow[t]{2}{*}{ df } & \multirow{2}{*}{$\begin{array}{l}\text { Sig. } \\
(2- \\
\text { tailed } \\
)\end{array}$} & \multirow[t]{2}{*}{$\begin{array}{c}\text { Mean } \\
\text { Differen } \\
\text { ce }\end{array}$} & \multirow{2}{*}{\begin{tabular}{|c|} 
Std. \\
Error \\
Differenc \\
e
\end{tabular}} & \multicolumn{2}{|c|}{$\begin{array}{l}95 \% \text { Confide } \\
\text { nce Interval of } \\
\text { the Difference }\end{array}$} \\
\hline & & & & & & & & & Lower & $\underset{\mathbf{r}}{\text { Uppe }}$ \\
\hline \multirow{2}{*}{$\begin{array}{l}\text { The reading exercises } \\
\text { and tasks in the } \\
\text { course book were } \\
\text { suitable for my level. }\end{array}$} & $\begin{array}{l}\text { Equal variances } \\
\text { assumed }\end{array}$ & .752 & .387 & $\begin{array}{l}- \\
2.282\end{array}$ & 146 & .024 & -.515 & .226 & -.961 & -.069 \\
\hline & \begin{tabular}{|l|} 
Equal variances \\
not assumed
\end{tabular} & & & $\begin{array}{l} \\
2.283\end{array}$ & $\begin{array}{l}145 . \\
998\end{array}$ & .024 & -.515 & .225 & -.961 & -.069 \\
\hline \multirow{2}{*}{$\begin{array}{l}\text { The course gave me } \\
\text { opportunities } \\
\text { practise speaking. }\end{array}$} & $\begin{array}{l}\text { Equal variances } \\
\text { assumed }\end{array}$ & 3.903 & .050 & .106 & 146 & .916 & .023 & .219 & -.410 & .457 \\
\hline & \begin{tabular}{|l|} 
Equal variances \\
not assumed
\end{tabular} & & & .105 & $\begin{array}{l}140 . \\
290\end{array}$ & .916 & .023 & .220 & -.412 & .458 \\
\hline \multirow{2}{*}{$\begin{array}{l}\text { The listening activities } \\
\text { were suitable and } \\
\text { helped me develop my } \\
\text { listening skill. }\end{array}$} & $\begin{array}{l}\text { Equal variances } \\
\text { assumed }\end{array}$ & .160 & .690 & .140 & 146 & .889 & .032 & .226 & -.414 & .477 \\
\hline & \begin{tabular}{|l} 
Equal variances \\
not assumed
\end{tabular} & & & .140 & $\begin{array}{l}145 . \\
506\end{array}$ & .889 & .032 & .226 & -.414 & .478 \\
\hline \multirow[t]{2}{*}{$\begin{array}{l}\text { The writing tasks } \\
\text { were achievable. }\end{array}$} & $\begin{array}{l}\text { Equal variances } \\
\text { assumed }\end{array}$ & 288 & .592 & .310 & 146 & .757 & .066 & .214 & -.356 & .488 \\
\hline & \begin{tabular}{|l|} 
Equal variances \\
not assumed
\end{tabular} & & & .309 & $\begin{array}{l}145 . \\
035\end{array}$ & .758 & .066 & .214 & -.356 & .489 \\
\hline \multirow{2}{*}{$\begin{array}{l}\text { The number of new } \\
\text { words introduced in } \\
\text { every lesson was appr } \\
\text { opriate for this level. }\end{array}$} & $\begin{array}{l}\text { Equal variances } \\
\text { assumed }\end{array}$ & 2.107 & .149 & .890 & 146 & .375 & .202 & .227 & -.246 & .649 \\
\hline & $\begin{array}{l}\text { Equal variances } \\
\text { not assumed }\end{array}$ & & & .888 & $\begin{array}{l}142 . \\
736\end{array}$ & .376 & .202 & .227 & -.247 & .650 \\
\hline \multirow{2}{*}{$\begin{array}{l}\text { The vocabulary exerci } \\
\text { ses in the course book } \\
\text { were suitable and } \\
\text { helped me learn new } \\
\text { vocabulary. }\end{array}$} & $\begin{array}{l}\text { Equal variances } \\
\text { assumed }\end{array}$ & 2.001 & .159 & 2.318 & 146 & .022 & .517 & .223 & .076 & .958 \\
\hline & \begin{tabular}{|l|} 
Equal variances \\
not assumed
\end{tabular} & & & 2.314 & $\begin{array}{l}141 . \\
411\end{array}$ & .022 & .517 & .224 & .075 & .959 \\
\hline
\end{tabular}


A Gender-Based Analysis of Saudi EFL Learners' Approaches towards Outcome-Based Education: Learning Outcomes and Teaching Resources in Focus

\begin{tabular}{|c|c|c|c|c|c|c|c|c|c|c|}
\hline $\begin{array}{l}\text { The grammar points } \\
\text { were presented with }\end{array}$ & \begin{tabular}{|l|} 
Equal variances \\
assumed
\end{tabular} & 2.962 & .087 & .772 & 146 & .441 & .176 & .228 & -.274 & .626 \\
\hline $\begin{array}{l}\text { appropriate examples } \\
\text { and explanations. }\end{array}$ & \begin{tabular}{|l|} 
Equal variances \\
not assumed
\end{tabular} & & & .770 & $\begin{array}{l}140 . \\
623\end{array}$ & .443 & .176 & .228 & -.275 & .627 \\
\hline $\begin{array}{|lr|}\text { There was } & \text { sufficient } \\
\text { attention } & \text { to }\end{array}$ & \begin{tabular}{|l|} 
Equal variances \\
assumed
\end{tabular} & 3.368 & .069 & .736 & 146 & .463 & .166 & .226 & -.280 & .612 \\
\hline $\begin{array}{l}\text { pronunciation and } \\
\text { individual sounds. }\end{array}$ & \begin{tabular}{|l|}
$\begin{array}{l}\text { Equal variances } \\
\text { not assumed }\end{array}$ \\
\end{tabular} & & & .734 & $\begin{array}{l}142 . \\
167\end{array}$ & .464 & .166 & .226 & -.281 & .613 \\
\hline $\begin{array}{l}\text { During this course I } \\
\text { participated fully in }\end{array}$ & $\begin{array}{l}\text { Equal variances } \\
\text { assumed }\end{array}$ & .719 & .398 & -.400 & 146 & .689 & -.092 & .231 & -.549 & .364 \\
\hline $\begin{array}{l}\text { class learning activity } \\
\text { es. }\end{array}$ & \begin{tabular}{|l|}
$\begin{array}{l}\text { Equal variances } \\
\text { not assumed }\end{array}$ \\
\end{tabular} & & & -.400 & $\begin{array}{l}144 . \\
960\end{array}$ & .690 & -.092 & .231 & -.549 & .364 \\
\hline
\end{tabular}

The above independent sample test suggests that there is no significant difference of opinion found between male and female students about various types of tasks and exercises integrated in the textbooks. Except for the reading exercise (p value ".024") and vocabulary exercises (p value ".022"), the $\mathrm{p}$ value for all other statements is above ".05,"which suggests that there is no difference of opinion between the male and female learners. The significant difference is found about reading and vocabulary exercises.

Table6. Effectiveness of Online Material towards Attainment of Learning Outcomes

\begin{tabular}{|l|l|l|l|}
\hline \multicolumn{1}{|c|}{ Online material } & N & Mean & $\begin{array}{c}\text { Std. } \\
\text { Deviation }\end{array}$ \\
\hline I used the on-line materials (English Unlimited). & 148 & 3.74 & 1.481 \\
\hline The online resources were useful and they supported my learning. & 148 & 2.38 & 1.280 \\
\hline Valid N (listwise) & 148 & & \\
\hline
\end{tabular}

It is very interesting to know that the majority of the students use the online material with mean value $(3.74 \pm 1.481)$. However, they think (mean value $2.38 \pm 1.280)$ that the online materials are not useful and thus they don't support their learning. This is a matter of concern for the publishers and the concerned administrative authorities to understand why such online material are not found useful by the students despite the fact that majority of the students use them.

Table7. Group Statistics and Independent Sample Tests on Effectiveness of Online Material towards Attainment of Learning Outcomes

\section{Group Statistics}

\begin{tabular}{|l|l|l|l|l|l|}
\hline \multicolumn{2}{|c|}{ Q3 } & \multicolumn{1}{|c|}{ N } & Mean & Std. Deviation & Std. Error Mean \\
\hline \multirow{2}{*}{$\begin{array}{l}\text { I used the on-line materials } \\
\text { (English Unlimited). }\end{array}$} & Male & 75 & 3.99 & 1.447 & .167 \\
\cline { 2 - 6 } & Female & 73 & 3.49 & 1.483 & .174 \\
\hline $\begin{array}{l}\text { The online resources were useful } \\
\text { and they supported my learning. }\end{array}$ & Male & 75 & 2.35 & 1.191 & .138 \\
\cline { 2 - 6 } & Female & 73 & 2.41 & 1.373 & .161 \\
\hline
\end{tabular}

\section{Independent Samples Test}

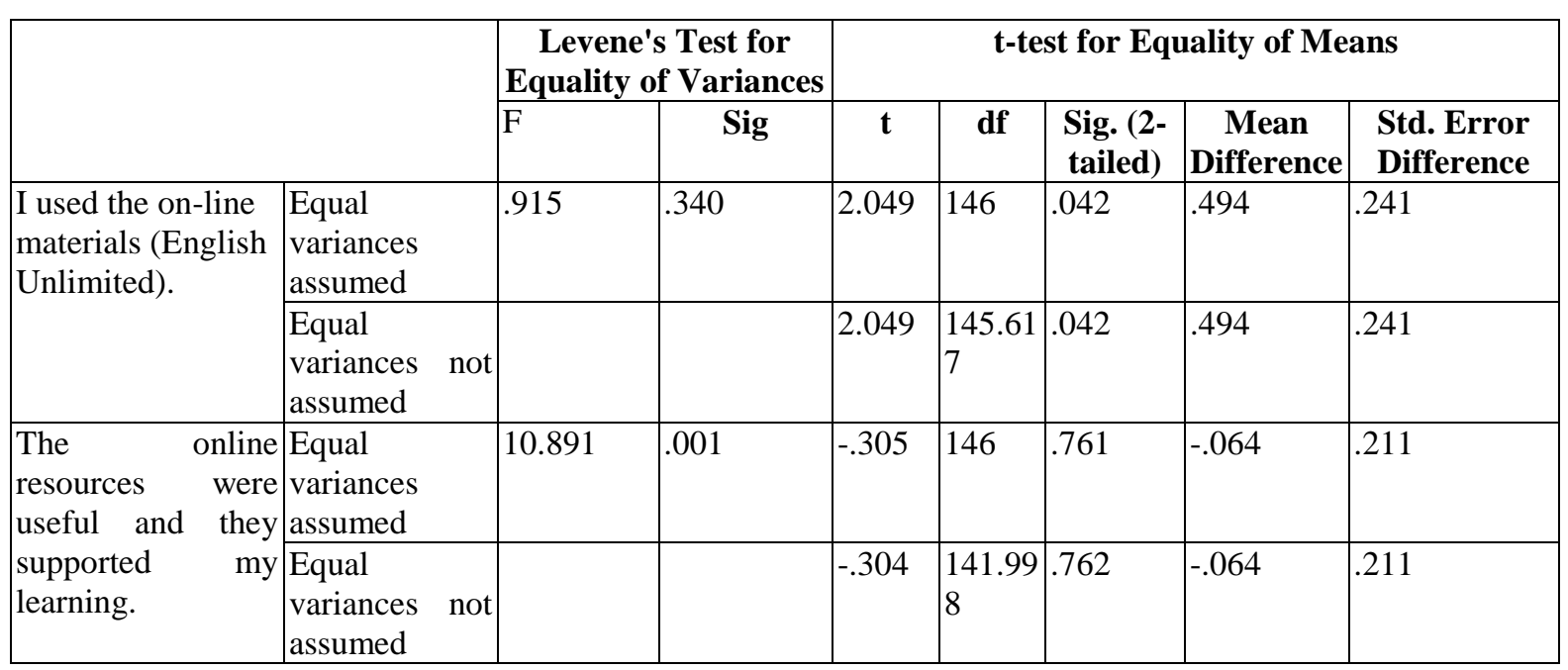


A Gender-Based Analysis of Saudi EFL Learners' Approaches towards Outcome-Based Education: Learning Outcomes and Teaching Resources in Focus

Comparing the mean value reported seperately for both male and female students against each question item of this section in the group Statistics Table, the results show that there is a small difference found between the opinions of male and female students. The male students with mean value (3.99 1.44) use the online resources more than the female students (3.49 1.48). Both the male and female students groups agree with each other, saying that the online materials are not useful to support their learning as the mean value for both is below the neutral value. However, the male students (2.35 1.19) disagree more in comparison with the female students $(2.411 .37)$ that the online material are useful. There is a signifianct difference found between the opinion of male and female students about using online material with $\mathrm{p}$ value "042"which is below ".05". However, no difference is found in their opinion about its usefulness. As Tshai, Ho, Yap and Ng (2014) suggest that the Continuous Quality Improvement feature of OBE calls for further investigation of any issue, the current problem regarding the learners' dissatisfaction about the online material needs to be investigated.

Table8. Effectiveness of Tasks and Activities towards Learning Outcomes

\begin{tabular}{|c|c|c|c|}
\hline Usefulness of task and activities & $\mathbf{N}$ & Mean & $\begin{array}{c}\text { Std. } \\
\text { Deviation }\end{array}$ \\
\hline $\begin{array}{l}\text { The tests in this course were directly related to the assignments, classroom } \\
\text { discussions and other activities. }\end{array}$ & 148 & 3.42 & 1.294 \\
\hline The feedback I received on my progress was useful. & 148 & 3.66 & 1.221 \\
\hline I have learnt a wide range of useful vocabulary. & 148 & 3.72 & 1.256 \\
\hline This English course has helped me improve my reading skills. & 148 & 3.63 & 1.274 \\
\hline This English course has helped me improve my writing skills. & 148 & 3.82 & 1.244 \\
\hline This English course has helped me improve my speaking skills. & 148 & 3.61 & 1.249 \\
\hline This English course has helped me improve my listening skills. & 148 & 3.57 & 1.279 \\
\hline I have improved my grammar skills. & 148 & 3.48 & 1.392 \\
\hline This course increased my interest in learning English. & 148 & 3.57 & 1.376 \\
\hline I would recommend this course to other students. & 148 & 2.10 & 1.276 \\
\hline
\end{tabular}

Looking at the above descriptive table shows that that mean value for nine out of ten statements is above the neutral value (2.5). This shows that the students in general, irrespective of their gender, largely agree that the tasks and activities are useful towards the attainment of their course learning outcomes. The highest mean value $(3.82 \pm 1.244)$ is reported for students, claiming that their learning of English through OBE helped them improve their writing skills, followed by learning a wide range of useful vocabulary $(3.72 \pm 1.25)$. However, this is very interesting to notice that the lowest mean value $(2.10 \pm 1.276)$ is reported for students saying that they would not recommend this course to others. This is in contrast with all other statements responded by the students. On the other hand, they agree that the tasks and exercises are useful for their attainment of the course learning outcomes.

Table9. Group Statistics on Effectiveness of Tasks and Activities towards Learning Outcomes

\begin{tabular}{|c|c|c|c|c|c|}
\hline \multicolumn{6}{|c|}{ Group Statistics } \\
\hline \multicolumn{2}{|l|}{ Q3 } & $\mathbf{N}$ & Mean & $\begin{array}{c}\text { Std. } \\
\text { Deviation }\end{array}$ & $\begin{array}{l}\text { Std. Error } \\
\text { Mean }\end{array}$ \\
\hline \multirow{2}{*}{$\begin{array}{l}\text { The tests in this course were directly } \\
\text { related to the assignments, classroom } \\
\text { discussions and other activities. }\end{array}$} & Male & 75 & 3.60 & 1.174 & .136 \\
\hline & Female & 73 & 3.23 & 1.390 & .163 \\
\hline \multirow{2}{*}{$\begin{array}{l}\text { The feedback I received on my progress } \\
\text { was useful. }\end{array}$} & Male & 75 & 3.99 & 1.072 & .124 \\
\hline & Female & 73 & 3.33 & 1.281 & .150 \\
\hline \multirow{2}{*}{$\begin{array}{l}\text { I have learnt a wide range of useful } \\
\text { vocabulary. }\end{array}$} & Male & 75 & 3.99 & 1.084 & .125 \\
\hline & Female & 73 & 3.44 & 1.364 & .160 \\
\hline \multirow{2}{*}{$\begin{array}{l}\text { This English course has helped me } \\
\text { improve my reading skills. }\end{array}$} & Male & 75 & 3.88 & 1.162 & .134 \\
\hline & Female & 73 & 3.37 & 1.339 & .157 \\
\hline \multirow{2}{*}{$\begin{array}{l}\text { This English course has helped me } \\
\text { improve my writing skills. }\end{array}$} & Male & 75 & 4.04 & 1.071 & .124 \\
\hline & Female & 73 & 3.60 & 1.372 & .161 \\
\hline \multirow{2}{*}{$\begin{array}{l}\text { This English course has helped me } \\
\text { improve my speaking skills. }\end{array}$} & Male & 75 & 3.83 & 1.132 & .131 \\
\hline & Female & 73 & 3.38 & 1.329 & .156 \\
\hline \multirow{2}{*}{$\begin{array}{l}\text { This English course has helped me } \\
\text { improve my listening skills. }\end{array}$} & Male & 75 & 3.73 & 1.095 & .126 \\
\hline & Female & 73 & 3.40 & 1.431 & .168 \\
\hline
\end{tabular}


A Gender-Based Analysis of Saudi EFL Learners' Approaches towards Outcome-Based Education: Learning Outcomes and Teaching Resources in Focus

\begin{tabular}{|l|l|l|l|l|l|}
\hline I have improved my grammar skills. & Male & 75 & 3.60 & 1.284 & .148 \\
\cline { 2 - 6 } & Female & 73 & 3.36 & 1.494 & .175 \\
\hline \multirow{2}{*}{$\begin{array}{l}\text { This course increased my interest in } \\
\text { learning English. }\end{array}$} & Male & 75 & 3.53 & 1.329 & .153 \\
\cline { 2 - 6 } & Female & 73 & 3.60 & 1.431 & .168 \\
\hline \multirow{2}{*}{$\begin{array}{l}\text { I would recommend this course to other } \\
\text { students. }\end{array}$} & Male & 75 & 1.95 & 1.293 & .149 \\
\cline { 2 - 6 } & Female & 73 & 2.26 & 1.248 & .146 \\
\hline
\end{tabular}

As such, there doesn't seem to be any stark difference between the views of the students about the efficacy of these tasks for their learning outcomes. They largely agree with each other that the tasks are useful for their learning. In this regard, the biggest disagreement in the opinions of the male and female students was reported about the usefulness of the received feedback (male 3.99 and female 3.33), followed by their learning of the useful vocabulary (male 3.99 female 3.44). The biggest agreement between the male and female learners is noticed in their saying that this course enhances their interest in learning English (male 3.53 female 3.60), followed by saying that English helps in improving their grammar skills (male 3.60 female 3.36).

Table10. Independent Sample Tests on Effectiveness of Tasks and Activities towards Learning Outcomes

\begin{tabular}{|c|c|c|c|c|c|c|c|c|c|c|}
\hline \multicolumn{11}{|c|}{ Independent Samples Test } \\
\hline & & \multicolumn{2}{|c|}{$\begin{array}{l}\text { Levene's Test } \\
\text { for Equality } \\
\text { of Variances } \\
\end{array}$} & \multicolumn{7}{|c|}{ t-test for Equality of Means } \\
\hline & & $\mathbf{F}$ & Sig. & $\mathbf{t}$ & Df & \begin{tabular}{|c|} 
Sig. \\
$(2-$ \\
tailed $)$
\end{tabular} & $\begin{array}{c}\text { Mean } \\
\text { Differe } \\
\text { nce }\end{array}$ & $\begin{array}{c}\text { Std. } \\
\text { Error } \\
\text { Differe } \\
\text { nce }\end{array}$ & $\begin{array}{r}95 \\
\text { Confi } \\
\text { Inter } \\
\text { the Diff } \\
\text { Lower }\end{array}$ & $\begin{array}{l}\% \\
\text { dence } \\
\text { val of } \\
\text { ference } \\
\text { Upper } \\
\end{array}$ \\
\hline \begin{tabular}{|l} 
The tests in this \\
course were direct ly
\end{tabular} & \begin{tabular}{|l|} 
Equal variances \\
assumed
\end{tabular} & 4.081 & .045 & 1.738 & 146 & .084 & .367 & .211 & -.050 & .785 \\
\hline $\begin{array}{l}\text { related to the } \\
\text { assignments, class } \\
\text { room discussions and } \\
\text { other activities. }\end{array}$ & $\begin{array}{l}\text { Equal variances } \\
\text { not assumed }\end{array}$ & & & 1.734 & 140.713 & .085 & .367 & .212 & -.051 & .786 \\
\hline $\begin{array}{llr}\text { The feedback } & \mathrm{I} \\
\text { received on my }\end{array}$ & $\begin{array}{l}\text { Equal variances } \\
\text { assumed }\end{array}$ & 8.240 & .005 & 3.393 & 146 & .001 & .658 & .194 & .275 & 1.041 \\
\hline progress was useful. & $\begin{array}{l}\text { Equal variances } \\
\text { not assumed }\end{array}$ & & & 3.385 & 140.212 & .001 & .658 & .194 & .274 & 1.042 \\
\hline $\begin{array}{l}\text { I have learnt a wide } \\
\text { range of useful }\end{array}$ & $\begin{array}{l}\text { Equal variances } \\
\text { assumed }\end{array}$ & 6.506 & .012 & 2.711 & 146 & .008 & .548 & .202 & .149 & .948 \\
\hline vocabulary. & \begin{tabular}{|l|}
$\begin{array}{l}\text { Equal variances } \\
\text { not assumed }\end{array}$ \\
\end{tabular} & & & 2.703 & 137.269 & .008 & .548 & .203 & .147 & .949 \\
\hline \begin{tabular}{|lrr} 
This & English & course \\
has & helped & me
\end{tabular} & \begin{tabular}{|l|} 
Equal variances \\
assumed
\end{tabular} & 3.516 & .063 & 2.478 & 146 & .014 & .510 & .206 & .103 & .917 \\
\hline $\begin{array}{l}\text { improve my reading } \\
\text { skills. }\end{array}$ & $\begin{array}{l}\begin{array}{l}\text { Equal variances } \\
\text { not assumed }\end{array} \\
\end{array}$ & & & 2.473 & 142.017 & .015 & .510 & .206 & .102 & .918 \\
\hline $\begin{array}{|lrr|}\text { This } & \text { English } & \text { course } \\
\text { has } & \text { helped } & \text { me }\end{array}$ & $\begin{array}{l}\text { Equal variances } \\
\text { assumed }\end{array}$ & 7.152 & .008 & 2.165 & 146 & .032 & .437 & .202 & .038 & .836 \\
\hline $\begin{array}{l}\text { improve my writing } \\
\text { skills. }\end{array}$ & $\begin{array}{l}\text { Equal variances } \\
\text { not assumed }\end{array}$ & & & 2.158 & 136.151 & .033 & .437 & .203 & .036 & .838 \\
\hline $\begin{array}{|lrr|}\text { This } & \text { English } & \text { course } \\
\text { has } & \text { helped } & \text { me }\end{array}$ & $\begin{array}{l}\text { Equal variances } \\
\text { assumed }\end{array}$ & 3.498 & .063 & 2.186 & 146 & .030 & .443 & .203 & .042 & .844 \\
\hline $\begin{array}{l}\text { improve my speaking } \\
\text { skills. }\end{array}$ & $\begin{array}{l}\text { Equal variances } \\
\text { not assumed }\end{array}$ & & & 2.181 & 141.083 & .031 & .443 & .203 & .041 & .845 \\
\hline \begin{tabular}{|lrr} 
This & English & course \\
has & helped & me
\end{tabular} & $\begin{array}{l}\text { Equal variances } \\
\text { assumed }\end{array}$ & 10.272 & .002 & 1.607 & 146 & .110 & .336 & .209 & -.077 & .749 \\
\hline $\begin{array}{l}\text { improve my listening } \\
\text { skills. }\end{array}$ & $\begin{array}{l}\text { Equal variances } \\
\text { not assumed }\end{array}$ & & & 1.602 & 134.809 & .112 & .336 & .210 & -.079 & .751 \\
\hline \multirow[t]{2}{*}{$\begin{array}{l}\text { I have improved my } \\
\text { grammar skills. }\end{array}$} & $\begin{array}{l}\text { Equal variances } \\
\text { assumed }\end{array}$ & 3.296 & .072 & 1.066 & 146 & .288 & .244 & .229 & -.208 & .696 \\
\hline & $\begin{array}{l}\text { Equal variances } \\
\text { not assumed }\end{array}$ & & & 1.064 & 141.549 & .289 & .244 & .229 & -.209 & .697 \\
\hline
\end{tabular}


A Gender-Based Analysis of Saudi EFL Learners' Approaches towards Outcome-Based Education: Learning Outcomes and Teaching Resources in Focus

\begin{tabular}{|c|c|c|c|c|c|c|c|c|c|c|}
\hline \begin{tabular}{|l} 
This course increased \\
my interest in
\end{tabular} & $\begin{array}{l}\text { Equal variances } \\
\text { assumed }\end{array}$ & .263 & .609 & -.306 & 146 & .760 & -.069 & .227 & -.518 & .379 \\
\hline learning English. & $\begin{array}{l}\text { Equal variances } \\
\text { not assumed }\end{array}$ & & & -.306 & 144.519 & .760 & -.069 & .227 & -.518 & .380 \\
\hline $\begin{array}{l}\text { I would recommend } \\
\text { this course to other }\end{array}$ & $\begin{array}{l}\text { Equal variances } \\
\text { assumed }\end{array}$ & .007 & .934 & $\mid-1.501$ & 146 & .136 & -.314 & .209 & -.727 & .099 \\
\hline students. & $\begin{array}{l}\text { Equal variances } \\
\text { not assumed }\end{array}$ & & & $\mid-1.502$ & 145.989 & .135 & -.314 & .209 & -.726 & .099 \\
\hline
\end{tabular}

The difference of opinion among the male and female students is reported more in this section, compared to all other sections. The independent sample test suggests that there is a statistically significant difference found about the various statements from this section. The highly significant difference is observed about the nature of feedback received by the students on their progress with $p$ value .001, which is far below the threshold line .05 . There is also a highly significant difference reported with $\mathrm{p}$ value of.008 about learning a wide range of vocabulary. In addition, the significant difference was also reported about their claims for saying that this course helps improve writing skills ( $\mathrm{p}$ value .032) and speaking skills ( $\mathrm{p}$ value .030). Apart from these statements, there are no significant differences found among the opinions of the students about the usefulness of the tasks and activities for developing the language skills.

\section{CONClusion}

This study quantitatively analyzed the viewpoints of male and female students to see if there are differences in their perceptions towards the effectiveness of Outcome-Based Education (OBE) in their English as a Foreign Language (EFL) classroom. It was found out that all the 75 and male and 73 female students who responded to the questions expressed their confidence in OBE as an effective system of teaching and assessment in their EFL classroom. The research also investigated the male and female students' responses to see if there are variations in their opinions regarding the effectiveness and sufficiency of the textbooks as well as the online study material towards the achievement of the course learning outcomes. The findings of the study showed that despite that all the male and female students believe in the sufficiency and efficacy of the textbooks towards the achievement of learning outcomes, they did not feel that the online material was effective towards achieving their overall targets. This issue came forth as one of the findings of the study, where all the students have been using the online resources provide by the publisher of the textbooks, but, at the same time, they believe that these online resources are ineffective. Future researchers may take up this issue for further investigation. There was also a difference of opinion found between the male and female learners in terms of the feedback that they received from their teachers. This issue may also be further investigated by future researchers. Overall, all male and female learners expressed their confidence in the OBE in general as well as the efficacy and sufficiency of the teaching material in their EFL classrooms.

\section{ACKNOWLEDGEMENTS}

This is to acknowledge the support of Cambridge University Press research team as well as the Research \& Curriculum Unit of Taif University English Language Centre in the accomplishment of this article.

\section{REFERENCES}

[1] Brookhart, S. M. (2015). Graded achievement, tested achievement, and validity. Educational Assessment, 20(4), 268-296.doi:10.1080/10627197.2015.1093928

[2] FirdevsMelisCin, EcemKarlıdağ-Dennis \& Zeynep Temiz (2018) Capabilities-based gender equality analysis of educational policy-making and reform in Turkey, Gender and Education, DOI: 10.1080/0954 0253.2018 .1484429

[3] Christian Lundahl, Magnus Hultén\&SverreTveit (2017) The power of teacher-assigned grades in outcomebased education, Nordic Journal of Studies in Educational Policy, 3:1, 56-66, DOI: 10.1080/20020317.20 17.1317229

[4] Cummings, W. K. and Williams, J. (2005). International Development Models for Educational Reform. Asia Pacific Journal of Education, Vol. 25, No. 2, pp. 125-143.

[5] Haidar M. Harmanani (2017) An outcome-based assessment process for accrediting computing programmes, European Journal of Engineering Education, 42:6, 844-859, DOI: 10.1080/03043797.2016 .1226781 
A Gender-Based Analysis of Saudi EFL Learners' Approaches towards Outcome-Based Education: Learning Outcomes and Teaching Resources in Focus

[6] John James Okiror, Geoff Hayward \& Mark Winterbottom (2017) Towards in-service training needs of secondary school agriculture teachers in a paradigm shift to outcome-based education in Uganda, The Journal of Agricultural Education and Extension, 23:5, 415-426, DOI: 10.1080/1389224X.2017.1338593

[7] K.Y. Tshai, J.-H. Ho, E.H. Yap \& H.K. Ng (2014) Outcome-based Education - The Assessment of Programme Educational Objectives for an Engineering Undergraduate Degree, Engineering Education, 9:1, 74-85, DOI: 10.11120/ened.2014.00020

[8] Marie J. Lindhorst and Janet K. Schulenlenberg, Defining and Measuring Student Learning Outcomes, Fifth Annual Professional Development Conference on Academic Advising, University Park, PA September 27-28, 2006.

[9] Poly. U. (2008). Guide to Outcome-Based Education. Learning and Teaching Committee of The Hong Kong Polytechnic University (http://www.polyu.edu.hk/obe; accessed in December 2008).

[10] Ruhland, S.K., \& Brewer, J.A. (2001) Implementing an assessment plan to document student learning in a two-year technical college. Journal of Vocational Education Research, 26, 141-171.

[11] Satish G. Jangali\& Vinayak N. Gaitonde (2019) Attaining competencies in Programme Outcomes through Open-Ended Experiments, Africa Education Review, DOI: 10.1080/18146627.2018.1481757

[12] Spady, W. G. (1994). Outcome-Based Education: Critical Issues and Answers. Arlington: American Association of School Administrators.

[13] Spady, W. G. (2003). Outcome Based Education. In Guthrie, J. W. (Editor), Encyclopediaof Education, $2^{\text {nd }}$ ed., pp. 1827-1831. New York: Macmillan Reference

[14] Ungar, H. G. (Editor, 1996). Encyclopedia of American Education. New York: Facts on File.

\section{AUTHORS' BIOGRAPHY}

Dr Mansoor S. Almalki is an Assistant Professor of Applied Linguistics, Dean of Supportive Studies and Director of English Language Centre at Taif University in Saudi Arabia. He has got his PhD from the University of Melbourne, Australia (Language Assessment), MA in TESOL, Cambridge Train the Trainer certificate, and CELTA Cambridge ESOL Examinations. He has taught English for several years in Saudi Arabia as well as in Australia. His main research interests include language assessment, blended approaches in language education, and qualitative research methods in applied linguistics.

Citation: Mansoor S. Almalki. "A Gender-Based Analysis of Saudi EFL Learners' Approaches towards Outcome-Based Education: Learning Outcomes and Teaching Resources in Focus." International Journal of Humanities Social Sciences and Education (IJHSSE), vol 6, no. 3, 2019, pp. 83-92 doi: http://dx.doi.org/10.20431/2349-0381.0603010.

Copyright: () 2019 Authors. This is an open-access article distributed under the terms of the Creative Commons Attribution License, which permits unrestricted use, distribution, and reproduction in any medium, provided the original author and source are credited. 